\title{
Paul Dudley White (1886-1973): Pioneer in modern cardiology
}

\author{
Siang Yong $\underline{\operatorname{Tan}}^{1}$, MD, JD, Erika $\underline{K w o c k}^{2}$
}

p $\mathrm{n}$ the annals of medical history, the heart has intrigued not only physicians but also other individuals such as poets, shamans and sorcerers. Ancient observers lent fanciful interpretations to notions of lovesickness and heartbreak, while recognising the seriousness of conditions like angina and dropsy (oedema, typically from heart failure). Physicians of the 19th century knew little about coronary artery disease, valvular heart disease, cardiac arrhythmias and cardiomyopathy. With the dawning of the 20th century, however, new discoveries - the radiograph, electrocardiograph (ECG) and cardiac catheter, to name a few - transformed the ability of doctors to diagnose and treat heart disease. One of the pioneers who ushered in the era of modern cardiology was an American physician named Paul Dudley White.

BORN INTO MEDICINE The son of a general practitioner, White was born on 6 June 1886, the second of four children. His early education was at Roxbury Latin School in Massachusetts, where he excelled in academics, ball sports and fencing. In 1904, he enrolled at Harvard College with tentative plans to become a teacher, then impulsively changed his mind to take up forestry, a decision that he regretted within weeks. White subsequently signed up for a premedical programme and entered Harvard Medical School in 1907. During medical school, his younger sister Dorothy, who contracted rheumatic fever as a

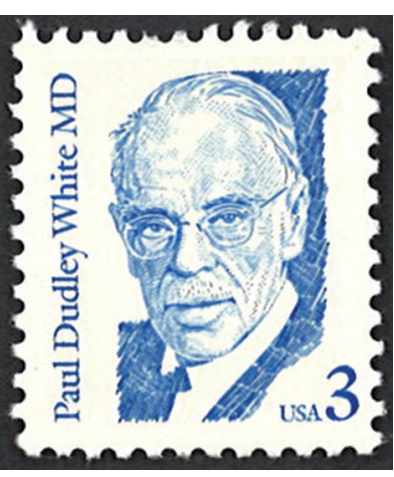

its saline bath electrodes and began compiling ECG tracings in his clinical research. He studied numerous cases of auricular fibrillation and recorded the ECG effects of digitalis, which was then the most widely prescribed heart drug. White observed prolonged conduction time in patients taking digitalis, going so far as to experiment on himself and willing colleagues. He also described the ECG features of pulmonary embolism.

AFFAIRS OF THE HEART In 1924, romance beckoned. A young woman named Ina Reid, who was studying to become a social worker, had been assigned to Massachusetts General Hospital and tasked with caring for patients with chorea, a manifestation of rheumatic fever. At that time, White was researching rheumatic fever clusters in families and teamed up with Reid for the 1,000 home visits that his study required. The collaboration led to a publication on rheumatic fever and wedding bells for the couple.

PRE-EXCITATION SYNDROME One case that helped immortalise White's place in medical history was that of an 18-year-old college freshman on the Harvard swim team. The young man narrated a four-year history of sudden episodes of rapid heartbeats, each lasting about 15 minutes. The results of his physical examination were completely normal, but his ECG was unusual, with a shortened P-R interval young child, died of complicating endocarditis and pericarditis. The event left a lasting impression and provided the impetus for his professional interest in rheumatic fever. White received his medical degree in 1911 and won a coveted internship position at the West Medical Service of Massachusetts General Hospital, USA, intending to specialise in paediatrics.

EARLY SPRINT During the internship, White collaborated with Dr Roger I Lee, a young staff member, in a research project to find an inexpensive and relatively quick test to measure clotting time. In 1913, they published a study in The American Journal of the Medical Sciences, which provided the basis for the Lee-White coagulation time measurement. It was a noteworthy achievement for a beginner physician. Later that year, White travelled to London to learn about a new diagnostic tool, the ECG, under the tutelage of Dr Thomas Lewis, a prominent cardiologist and editor of the journal Heart. Upon his return to Boston, White taught his colleagues the use of this promising new machine with and prolonged QRS duration. Coincidentally, 11 days later, one of White's cardiology fellows in the department, Dr Louis Wolff, referred a 35-year-old male gymnast. He presented with a similar ten-year history of frequent episodes of rapid irregular heartbeats precipitated by exercise or excitement, each lasting 30 minutes. Wolff and White scoured the medical literature, but could not find any detailed description of this condition, except for two case reports of young men who had been seen at the hospital previously. In 1930, White and Wolff published their observations in the American Heart Journal. This landmark article described what would become known as Wolff-Parkinson-White or pre-excitation syndrome, an arrhythmia caused by abnormal accessory conduction pathways between the heart chambers.

PHYSICIAN TO ALL White was painstaking in the way he elicited a medical history and examined patients, most of whom were ordinary folk. He delivered the best care to everyone, "from the President of the United States to the poor

${ }^{1}$ Emeritus Professor of Medicine, University of Hawaii, ${ }^{2}$ Research carried out as a 4th year medical student at the John A Burns School of Medicine, University of Hawaii, Honolulu, USA Correspondence: Prof Tan Siang Yong, 2226 Liliha Street, Suite B-104, Honolulu, HI 96817, USA. siang@hawaii.edu 
little lady coming in from the clinic. Everybody was equally welcome. He treated them all as gentlefolk, not as kings and not as paupers, but with universal humanity which obviously sprang from the heart". He counted many prominent citizens as his patients, such as American businessmen Cornelius Vanderbilt and Andrew Carnegie, as well as the Presidents of Nicaragua, Colombia and the Philippines. His most famous patient was American President Dwight Eisenhower, who suffered a heart attack in 1955. Many assumed that this would be either a fatal or debilitating event for the President, but White did much to dispel this view, telling the press that "carrying on" was an important part of recovery. He also advised that "if you could contribute to a man's happiness, you could probably add to his life". Eisenhower went on to successfully run for a second presidential term.

PRESCRIPTION FOR LIFE At the height of his career, White became an ardent promoter of habits conducive to good health, including those that improved mental and physical wellness. Following the Eisenhower case, White wrote an article on preventing heart attacks, which appeared on the front page of The New York Times and other newspapers. The article was said to have reached an audience of over 50 million readers. White presented a philosophy for a healthy way of life that included three main elements: optimism, regular physical activity and work. He was a staunch proponent of vigorous exercise (bicycling was his favourite), which was somewhat contrary to the medical opinion at the time that physical exertion could damage the heart. White was among the first to recognise the critical role of cardiac rehabilitation, now firmly established as a standard practice in patients after myocardial infarction. He also believed that having hope and a positive attitude toward life would maintain health and prevent illness. Above all, he believed that work was good for both mental and physical health, disavowing the practice of early retirement.

White was a founding member of the American Heart Association, which came into existence in 1922; in 1931, he published the classic text Heart Disease. In 1949, White was named the first chairman of the National Advisory Heart Council and provided the impetus for the Framingham Heart Study that identified the risk factors of coronary disease. He travelled widely, and was a welcomed and revered lecturer in all four corners of the world, including the Soviet Union and China. In 1948, White was named president of the International Society of Cardiology.

THE MAN BEHIND THE STETHOSCOPE Even as a young boy, White sported boundless energy and a compulsive attention to detail. His childhood diary listed countless names, dates and places, including minutiae regarding his height and weight, hat, shoe and collar sizes, and bicycle and watch registration numbers. This attention to detail undoubtedly sharpened his observational acumen as a cardiologist. White also wrote of long walks and bicycle rides, which he continued throughout his life and that likely accounted for his slender physique. He was an indefatigable force with one enduring hobby - a special collection of old medical books in Latin and Greek, which he was able to read, as he was literate in both languages. He was kind, courteous and generous, displaying genuine concern and care for people around him, such as showing up on Christmas with roses for patients and staff. An admiring colleague called him 'the Gentle Titan', adding: "In cardiology, populated by prima donna of all ages, he was an ageless gentleman."

At the age of 84 , White suffered a mild heart attack, but continued working and exercising. Three years later, he sustained a stroke and subdural haematoma. A second stroke followed shortly after and proved fatal. White died on 31 October 1973 at the age of 87. On that day, the world lost the man Time Magazine dubbed 'Dr Cardiology', whose pioneering work in preventive cardiology positively impacted the lifestyle of millions in the United States and abroad.

\section{BIBLIOGRAPHY}

- Davies MK, Hollman A. Paul Dudley White (1886-1973). Heart 1996; 76:182.

- Krikler DM. Thomas Lewis, a father of modern cardiology. Heart 1997; 77:102-3.

- Lee RI, White PD. A clinical study of the coagulation time of blood. Am J Med Sci 1913; 145:495-503.

- Spodick DH. Editorial: P.D.W.-the gentle titan Paul Dudley White, June 6, 1886--Oct 31, 1973. JAMA 1973; 226:1459.

- Paul O. Take Heart-The Life and Prescription for Living of Dr. Paul Dudley White. Boston: The Harvard University Press, 1986.

- Smith KS. Paul Dudley White. Br Heart J 1974; 36:608.

- Wolff L, Parkinson J, White PD. Bundle-branch block with short P-R interval in healthy young people prone to paroxysmal tachycardia. 1930. Am Heart J 1930; 5:685-704.

- Medicine: Dr. Cardiology. Available at: http://www.time.com/time/ magazine/article/0,9171,944687,00.html. Accessed March 4, 2008. 